\title{
Facultative Stabilization Pond: Measuring Biological Oxygen Demand using Mathematical Approaches
}

\author{
Ihsan Wira $\mathrm{S}^{1, *}$ and Sunarsih Sunarsih ${ }^{1,2}$ \\ ${ }^{1}$ Master Program of Environmental Science, School of Postgraduate Studies, Diponegoro University, Semarang - Indonesia \\ ${ }^{2}$ Faculty of Science and Mathematics, Diponegoro University, Semarang - Indonesia
}

\begin{abstract}
Pollution is a man-made phenomenon. Some pollutants which discharged directly to the environment could create serious pollution problems. Untreated wastewater will cause contamination and even pollution on the water body. Biological Oxygen Demand (BOD) is the amount of oxygen required for the oxidation by bacteria. The higher the BOD concentration, the greater the organic matter would be. The purpose of this study was to predict the value of BOD contained in wastewater. Mathematical modeling methods were chosen in this study to depict and predict the BOD values contained in facultative wastewater stabilization ponds. Measurements of sampling data were carried out to validate the model. The results of this study indicated that a mathematical approach can be applied to predict the BOD contained in the facultative wastewater stabilization ponds. The model was validated using Absolute Means Error with 10\% tolerance limit, and AME for model was $7.38 \%(<10 \%)$, so the model is valid. Furthermore, a mathematical approach can also be applied to illustrate and predict the contents of wastewater.
\end{abstract}

\section{Introduction}

The capital cities in Indonesia have some problems about environment quality, especially at settlements, so the greater population the more pollution increase $[1,2]$. The waste of settlements are always domestic wastes. Untreated domestic wastes from settlements will cause water pollution at the river. So, to decrease pollutant concentration, we need to treat those domestic wastewater before disposed to environment [3, 4]. Wastewater Stabilization Pond (WSP) is considered as the most suitable system to treat urban wastewater in tropical and subtropical regions and used for improving quality of water $[2,4,5,6,7,8]$. Stabilization pond also relies on natural processes of wastewater treatment by using the presence of microorganisms on it $[2,3,9]$. Those microorganisms could reduce organic matter of pollutant contained in pond [2]. One part of stabilization pond system is facultative pond such as Waste Water Treatment Plants (WWTP) Sewon in Bantul, Indonesia. WWTP Sewon was established to treat domestic wastewater from Yogyakarta City, Sleman Regency, and Bantul Regency.

Biological Oxygen Demand (BOD)is the amount of oxygen required by bacteria to oxidize organic matter in a wastewater [6]. The presence of BOD can be used as pollutant indicators. The greater oxygen in a wastewater, the smaller the contamination will be [2]. The change of BOD in wastewater also can describe the quality of that wastewater [2]. To know a quality of water, wastewater need to meet a requirement value of Biological Oxygen Demand (BOD). We need water sample data to know the amount of BOD of wastewater. However, the data only describe the existing condition of quality of wastewater in facultative ponds. So, we need a method to know condition/ prediction value of (BOD) by using previous data. It is worth it to use mathematical approach to predict BOD values next few days or months [3].

The purpose of this research is to depict degradation process by using mathematical model of BOD in facultative pond and to validate the model.

\section{Materials and Methods}

\subsection{Research Area Description}

Domestic wastewater from Yogyakarta City, Sleman Regency, and Bantul Regency is treated through WWTP Sewon in Bantul. The WWTP Sewon is located in Bantul regency and services domestic wastewater from almost 63.015 people [10].

WWTP Sewon has four facultative ponds and two maturation ponds. Fig.1 schematically shows the pond system. This research collected data from facultative II, as we see on the Fig.1 as well. So this research was using facultative II as taken sampling point to validate a model we have. 


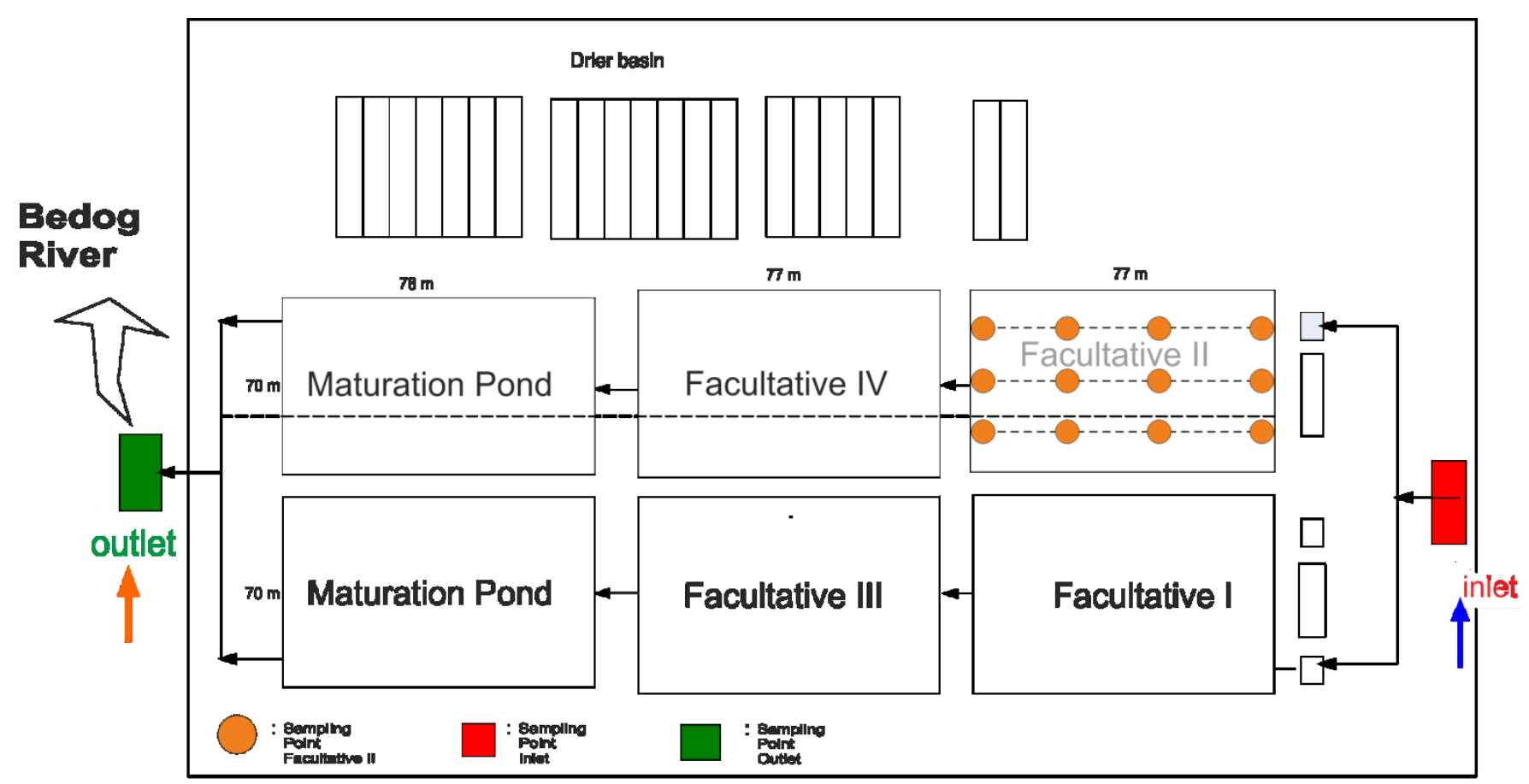

Fig. 1.Map of IPAL Sewon [4]

\subsection{Mathematical Model}

The model that could depict system process and environment as quantitative is mathematic model. The mathematical model is defined as the formulation of engineering problems into forms of mathematical equations based on the basic laws of physics, chemistry, and biology $[2,11]$. The following models are presented on an organic waste degradation Biological Oxygen Demand (BOD) process system in a stabilizing pond:

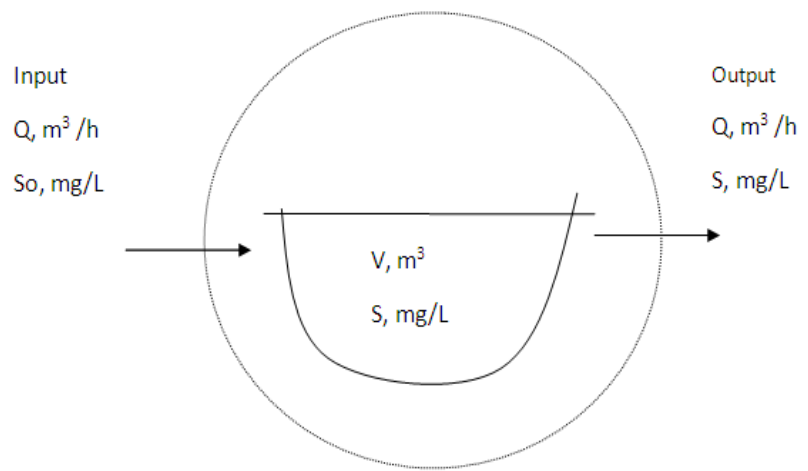

Fig.2.Diagram of stabilization pond [11]

And the following equation describes a degradation of BOD process in waste stabilization pond:[11].

$$
S=\left(\frac{Q S_{o}}{Q+k V}\right)+\left[S_{o}-\left(\frac{Q S_{o}}{Q+k V}\right)\right] e^{-\left(\frac{Q+k V}{V}\right) t}
$$

Where :

$S=$ BOD outfrom stabilization pond, $\mathrm{mg} / \mathrm{L}$

$S_{o}=$ BOD in stabilization pond, $\mathrm{mg} / \mathrm{L}$

$\mathrm{k}=$ degradation rate constant,

$\mathrm{V}=$ volume of pond, $\mathrm{m}^{3}$

$\mathrm{Q}=$ debit, $\mathrm{m}^{3} /$ time

$$
\mathrm{t}=\text { time period, }
$$

a valid model can be applied to simulate the system we have made [11].

\subsection{Validation Model}

A good model is a model that represents the real condition, physic process for specific condition, enough data, and requires the test of validation $[9,12]$. There are two validation of model, structure validation and performance validation. Structure validation is to get conviction about the construction of valid model scientifically or based on theory, while performance validation is to know how far model is appropriate/ compatible with performance real system or empiric data [1].

The model is validated to know the appropriateness of the formulated model, to know whether the model represented field condition or not with difference deviation between calculated data and observed data [9]. If the deviation is less than ( $10 \%$ tolerance limit), so the model is valid $[9,13]$.

Absolute Means Error (AME) is deviation between the average simulation value and actual value [13]. The following equation for AME :

$$
A M E=\left(\frac{\left|D_{a}-D_{s}\right|}{D_{a}}\right) \times 100 \%
$$

where : $D_{s}=$ Simulation data

$$
\begin{aligned}
& D_{a}=\text { Actual data } \\
& A M E=\text { Absolute Means Error }
\end{aligned}
$$

The model is valid if AME is less than $10 \%$, and if AME is more than $10 \%$ then the model must be evaluated.

\subsection{Sample and Data Analysis}

The water samples were measured on the facultative II in different time to get repeated measurement for concentration of BOD. The results of measurement were 
used to validate the model. The model that had been validated by comparing simulated model and observed model will be analyzed by AME.

\section{Results and Discussion}

\subsection{BOD of Facultative Stabilization Pond}

Wastewater discharge at Sewon Bantul WWTP has indicated approximately 10,697.53 $\mathrm{m}^{3} /$ time. The wastewater that had been treated through WWTP Sewo will be disposed to environment, Bedog River. Based on the Decree of the Governor of Yogyakarta Special Region No.214/KPTS/1991, Bedog River is registered as Class II with Standard Local Environment BOD value (effluent) below $50 \mathrm{mg} / \mathrm{L}$. The total volume of pond was $43,680 \mathrm{~m}^{3}$ and effective volume for facultative II was $8,085 \mathrm{~m}^{3}$ with $1.5 \mathrm{~m}$ depth.

The BOD inlet for the stabilization pond is approximately $180 \mathrm{mg} / \mathrm{L}$ as initial value for BOD with the coefficient of degradation was $1.85(k)$ [2].

Table.1. BOD Observation of Facultative II

\begin{tabular}{|c|c|c|c|c|}
\hline \multirow{2}{*}{ Times } & \multicolumn{4}{|c|}{ Biological Oxygen Demand (BOD) $(\mathrm{mg} / \mathrm{L})$} \\
\hline & $\begin{array}{c}06: 00 \\
\text { am }\end{array}$ & $\begin{array}{c}12: 00 \\
\text { pm }\end{array}$ & $\begin{array}{c}10: 00 \\
\text { pm }\end{array}$ & $\begin{array}{c}\text { Average of certain } \\
\text { sample }\end{array}$ \\
\hline Sample 1 & 93.72 & 72.34 & 64.32 & 76.79 \\
\hline Sample 2 & 63.22 & 51.42 & 74.52 & 63.05 \\
\hline Sample 3 & 71.32 & 58.48 & 75.16 & 68.32 \\
\hline Sample 4 & 51.32 & 75.88 & 133.84 & 87.01 \\
\hline Sample 5 & 48.32 & 75.64 & 112.60 & 78.85 \\
\hline Sample 6 & 88.54 & 80.42 & 64.08 & 77.68 \\
\hline Sample 7 & 49.52 & 66.36 & 103.56 & 73.15 \\
\hline Sample 8 & 82.30 & 77.24 & 52.20 & 70.58 \\
\hline Sample 9 & 67.58 & 91.57 & 64.52 & 74.56 \\
\hline $\begin{array}{l}\text { Sample } \\
10\end{array}$ & 67.20 & 63.32 & 73.96 & 68.16 \\
\hline $\begin{array}{l}\text { Sample } \\
\quad 11\end{array}$ & 48.32 & 58.32 & 72.96 & 59.87 \\
\hline $\begin{array}{l}\text { Sample } \\
12\end{array}$ & 41.89 & 62.84 & 63.96 & 56.23 \\
\hline $\begin{array}{l}\text { Average } \\
\text { of certain } \\
\text { time }\end{array}$ & 60.55 & 69.5 & 79.64 & 71.18 \\
\hline
\end{tabular}

The Table.1. indicated that the amount of BOD observation per day on facultative II was $71.18 \mathrm{mg} / \mathrm{L}$. That value was still more than $50 \mathrm{mg} / \mathrm{L}$ as a limit for Quality Standard as Class II to dispose to Bedog River. It happened because that amount is only on facultative II, there are still more to go to treat wastewater on the next ponds in WWTP Sewon.

The results of BOD simulation by equation (1),was run by Maple 2016 software describes the degradation process, where $S=$ BOD out from stabilization pond, $\mathrm{mg} / \mathrm{L}$

$S_{o}=250 \mathrm{mg} / \mathrm{L}$

$\mathrm{k}=0.6$

$\mathrm{V}=8,085 \mathrm{~m}^{3}$

$\mathrm{Q}=10,697.53 \mathrm{~m}^{3} /$ time

$\mathrm{t}=$ time period,

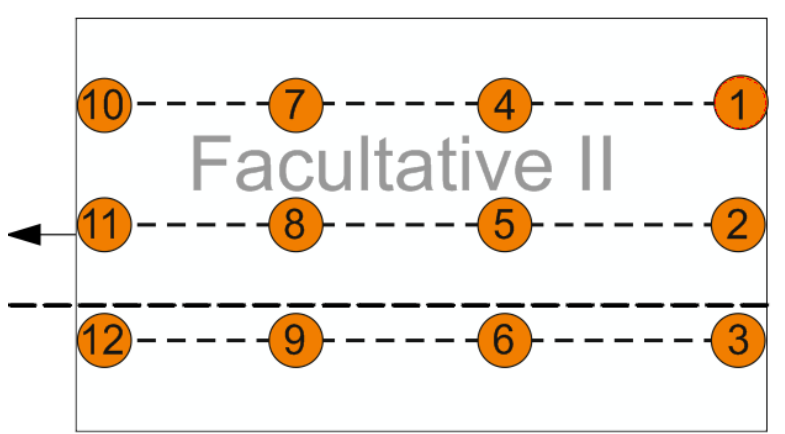

Fig.3. Sampling points of Facultative II

We have exponential equation

$S=75.05639885+104.9436012 e^{-3.173132962 t}$ the graphic showed that the BOD decreased exponentially from $180 \mathrm{mg} / \mathrm{L}$.

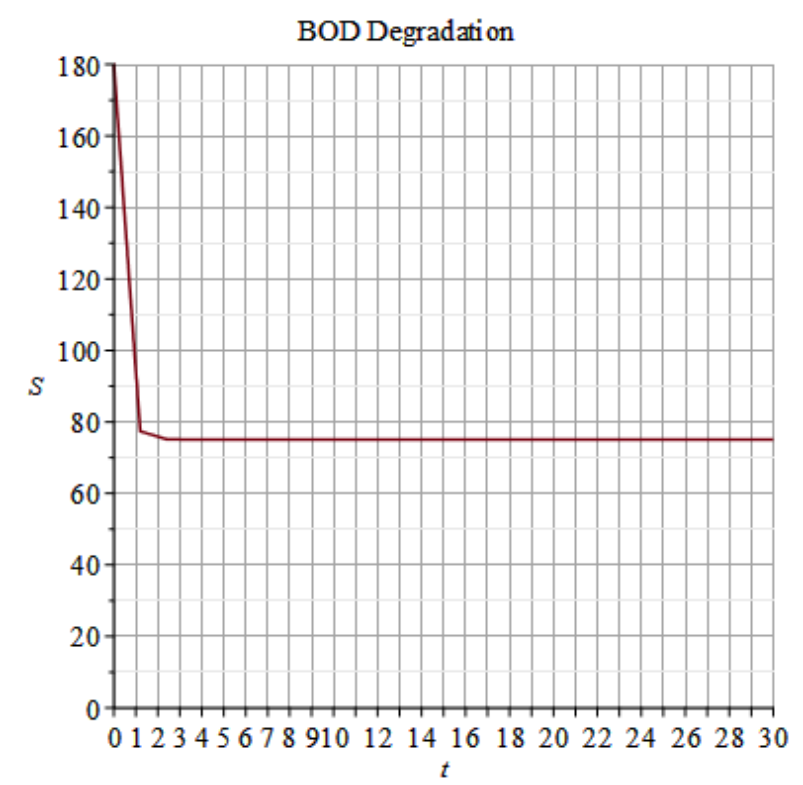

Fig.4.BOD Degradation

\subsection{Validation Testing}

The Absolute Means Error was calculated to validate the model. By using equation(2), the results of AME between BOD observation and BOD simulation is presented on Table.2.below. 
Table.2. AME between observation data and simulation data

\begin{tabular}{|c|c|c|}
\hline \multirow{2}{*}{ Time } & \multicolumn{2}{|c|}{ Biological Oxygen Demand (BOD) } \\
\cline { 2 - 3 } & BOD observation & BOD simulation \\
\hline $06: 00 \mathrm{am}$ & 60.55 & 75.056 \\
\hline $12: 00 \mathrm{pm}$ & 69.5 & 75.056 \\
\hline $10: 00 \mathrm{am}$ & 79.64 & 75.056 \\
\hline Average & 69.897 & 75.056 \\
\hline AME & $\mathbf{7 . 3 8 \%}<10 \%$ (tolerance limit) \\
\hline Conclusion & \multicolumn{2}{|c|}{ Valid } \\
\hline
\end{tabular}

\section{Conclusion}

The mathematical model can be applied to know and predict the value of BOD on the facultative pond. The model was validated by Absolute Means Error and the result was $7.38 \%$. It indicated the model is valid.

The amount of BOD is still greater than Quality Standard class II River. It happened because the measurement and model was only on the facultative II. Actually the BOD will continue be treated by next facultative and maturation ponds.

The authors really appreciate to the leaders and staff WWTP Sewon, Public Works Department, Housing and ESDM Local Government Yogyakarta who have given permission for the research and data collection of wastewater quality control at Sewon Bantul WWTP

\section{References}

1. Sunarsih. Permodelan Lingkungan Kualitas Air Limbah Pada Kolam Stabilisasi Fakultatif. Disertasi Semarang: Sekolah Pascasarjana, Universitas Diponegoro (2013)

2. Sunarsih.,Purwanto., W. S. Budi. IJTech 4 689-698 .(2015)

3. Sunarsih, D.P. Sasongko, Sutrisno.AJER5,01-05. (2016)

4. V.D.Leite ,G.B.A. Junior, J.T. Sousa, W.S.Lopes, I.N. JUEE 3 58-62 (2009)

5. M. Farzadki, M.H.Ehrampoush, S. Sadeghi, M. Kermani, M.T. Ghaneian, E.A. Mehrizi. EHEMJ 1 712 (2014)

6. Mara, Duncan. 2004. Domestic Waswater Treatment in Developing Countries. EarthScan: UK and USA.

7. WHO-World Health Organization Health guidelines for the use of water in agriculture and aquaclture. Geneva: World Health Organization. (Technical Report Series), 77 (1989)

8. S. Kayombo., T.S.A.Mbwette, A.W.Mayo, J.H.Y.Katima, S.E Jorgensen. EM 12721-31. (2000)

9. S. Sunarsih, P. Purwanto, W. S. Budi.JUEE 7 293301. (2013)

10. Sumarlan, N. Heksa,Physical Study to Determine Wastewater Quality of Was Water Treatment Plant (WWTP) Sewon, Bantul, Yogyakarta at The Opened Drain Canal. Skripsi Yogyakarta : Universitas Gadjah Mada.

11. Purwanto. 2005. Permodelan Rekayasa Proses dan Lingkungan. BadanPenerbitUniversitasDiponegoro: Semarang.

12. Muhammadi.,Aminullah,E., Soesilo, Budhi Analisis Sistem Dinamis. UMJ Press: Jakarta. 2001.

13. C. Musi, S. Anggoro, Sunarsih.JEE 18 25-34. 